\title{
Bir yönde perdeli 15 katlı yapının dinamik davranışının incelenmesi
}

\author{
Muhammet Zeki Özyurt ${ }^{1 *}$, Abdullah Zübeyr Hayval1 ${ }^{2}$ \\ ${ }^{1}$ Sakarya Üniversitesi, Mühendislik Fakültesi, İnşaat Mühendisliği Bölümü, Sakarya, Türkiye (ORCID: 0000-0002-1593-4581) \\ 2 İTÜ, Deprem Mühendisliği ve Afet Yönetimi Enstitüsü, Deprem Mühendisliği Anabilim Dalı, İstanbul, Türkiye (ORCID: 0000-0002-3670-4216)
}

(International Symposium on Multidisciplinary Studies and Innovative Technologies (ISMSIT) 2020 - 22-24 October 2020)

(DOI: 10.31590/ejosat.824708)

\begin{abstract}
ATIF/REFERENCE: Özyurt, M. Z. \& Hayvalı, A. Z. (2020). Bir yönde perdeli 15 katlı yapının dinamik davranışının incelenmesi. Avrupa Bilim ve Teknoloji Dergisi, (Özel Sayı), 369-380.
\end{abstract}

\begin{abstract}
$\ddot{O} \mathbf{z}$
Yapıların deprem davranışlarının belirlenmesi, deprem mühendisliği alanında günümüzde oldukça önemli bir yer tutmaktadır. Yapı sisteminin bütününün ve/veya yapısal elemanların deprem sırasında nasıl davranacağı uygun deneysel yöntemler ile önceden belirlenebilir. Bu amaçla kullanılan pek çok deneysel yöntem mevcuttur. Bunlardan biri sarsma tablası deneyleridir. Sarsma tablası deneyleri; gerçek dinamik yüklemelerdir. Bu çalışmada, 15 katlı olan ve köşelerinde sadece bir yönde perde bulunan bir yapı modeli incelenmiştir. Kullanım amacı işyeri olarak planlanan yapının geriye kalan taşıyıcı elemanları kolonlardan ve çerçeve kirişlerinden oluşmaktadır. Maket yapıda; kolon ve kiriş elemanlarının malzemesi kavak ağacından, perde elemanlarının malzemesi ise huş ağacından oluşmaktadır. Elemanlar bu malzemelerden üretilmiş olan çıtalar ve levhalar kullanılarak inşa edilmiştir. Yapının 1/100 ölçekli bir maketi yapılarak sarsma tablasına yerleştirilmiştir. Sarsma tablasına yerleştirilen yapı maketi, harmonik harekete maruz bırakılmıştır. Harmonik hareketinin frekansı kademeli olarak artıılarak üç farklı yer hareketi verilmiş, çok katlı yapı maketinde saniyelik ivme kaydı alınmıştır. Üç farklı depreme ait mevcut kayıtlı ivme değerleri uygulanarak, ağırlıklı ve ağırlıksız olarak yapının dinamik karakteristikleri elde edilmeye çalışılmışıtır. Maket yapının doğal frekansını elde etmek için serbest titreşim uygulanmış olup, SiesmoSignal programı kullanılmak suretiyle belirlenen ivme zaman kayıtları filtrelenmiştir. Deneysel çalışmanın yanı sıra, yapı Sap2000 programında modellenmiş ve Zaman Tanım Alanında Hesap Yöntemi kullanılarak dinamik analizleri yapılmıştır. Sarsma tablası deney sonuçları, Sap2000 programı ile yapılan dinamik analiz sonuçları ile karşılaştırılmıştır. Sonuç olarak ağırlıksız yapının sonuç kıyaslamasında sarsma tablası deneylerinden elde edilen sonuçlar ile Sap2000 programında yapılan dinamik analiz sonuçları arasında yaklaşı $\% 25^{\prime}$ lik fark olduğu belirlenmiştir. Ağırlıklı yapıda ise bu farkın yaklaşık \%50 olduğu görülmüştür. Diğer taraftan, her iki durumda da, deneysel çalışma ve Sap2000 analiz sonuçlarına bakııınca, periyot değerlerinin çok yakın çıktığı anlaşılmaktadır.
\end{abstract}

Anahtar Kelimeler: Sarsma tablası, Dinamik analiz, Harmonik hareket, Periyot, Çok katlı yapı, Perdeli yapı.

\section{Dynamic behavior of a walled 15-storey building in one direction}

\begin{abstract}
Determination of the earthquake behavior of buildings has an important place in the field of earthquake engineering today. The behavior of the whole structural system and/or structural elements during an earthquake can be determined in advance by appropriate experimental methods. There are many experimental methods used for this purpose. One of them is shake table experiments. Shake table experiments; are real dynamic loads. In this study, a 15-storey building model with curtains in only one direction at the corners was examined. The rest of the carrier elements of the building, which is planned as a workplace for the purpose of use, consist of columns and frame beams. In model structure; The material of column and beam elements is poplar wood, and the material of curtain elements is birch. Elements are constructed using laths and plates made of these materials. A 1/100 scale model of the building was made and placed on the shaking table. The building model placed on the shaking table was subjected to harmonic motion. By gradually increasing the frequency of the harmonic motion, three different ground motions were given, and the acceleration per second was recorded in the multi-storey building model. By applying the current recorded acceleration values for three different earthquakes, the dynamic characteristics of the structure were tried to be obtained, weighted and unweighted. In order to obtain the natural frequency of the model structure, free vibration was applied, and the acceleration time records determined by using the SiesmoSignal program were filtered. In addition to the experimental study, the structure was modeled in the Sap2000 program and dynamic analysis was performed
\end{abstract}


using the Time Domain Calculation Method. Shake table test results were compared with dynamic analysis results made with Sap2000 program. As a result, it was determined that there is approximately $25 \%$ difference between the results obtained from the shaking table tests and the results of the dynamic analysis made in the Sap2000 program in the result comparison of the unweighted structure. In the weighted structure, this difference was found to be approximately $50 \%$. On the other hand, when we look at the experimental study and Sap2000 analysis results in both cases, it is understood that the period values are very close.

Keywords: Shake table, Dynamic analysis, Harmonic motion, Period, Multi-storey structure, Shear-walled structure.

\section{Giriş}

Deprem, dünyada ve ülkemizde yapıların hasar görmesine veya çok sayıda can kaybına neden olan doğal bir afettir. Diğer taraftan ülkemizde yapılarının \%95'i deprem tehlikesi ile karşı karşıyadır. Bu nedenle, mevcut yapı stokunun önemli bir bölümü yıkılma veya hasar görme tehdidi altındadır. Son yıllarda meydana gelen depremler neticesinde mevcut yapı stokunun deprem performansı hakkında büyük oranda önemli bilgiler elde edilmiştir. Örneğin; 1999 Marmara Depremi Bolu, Bursa, Düzce, Eskişehir, İstanbul, Kocaeli, Sakarya, Yalova, Zonguldak illerini etkilemiş, 2010 yılında yayınlanan Meclis Araştırması Raporu'na göre 18.373 vatandaşımız ölmüş, 96 bin 796 konut ve 15 bin 939 işyeri kullanılamaz hale gelmiştir. Bu depremin merkez üssüne yaklaşık 120 km uzaklıkta olmasına rağmen, İstanbul'da 981 kişi hayatını kaybetmiş, Avcılar İlçesinde 1823 konut ve 326 işyeri kullanılamaz hale gelmiştir. İstanbul'da toplamda yaklaşık 4000 bina ağır hasar görmüştür (Özmen, B., 2000).

Yapıların deprem davranışlarının belirlenmesi, deprem mühendisliği alanında günümüzde oldukça önemli bir yer tutmaktadır. Yapıların doğrusal olmayan statik ve dinamik analizleri için birçok yöntem geliştirilmiştir ve halen bu alandaki çalışmalar hızla sürdürülmektedir (Atımtay, 2000). Doğrusal olmayan analiz yöntemlerinin genel amacı belirli bir deprem yükü seviyesi için yapıdan istenen deprem davranışının gerçekleşip gerçekleşmeyeceğinin kontrolüdür.

Yapı sisteminin bütününün ve/veya yapısal elemanların deprem sırasında nasıl davranacağı uygun deneysel yöntemler ile önceden belirlenebilir. Bu amaçla kullanılan pek çok deneysel yöntem mevcuttur. Bunlardan biri sarsma tablası deneyleridir. Sarsma tablası deneyleri; gerçek dinamik yüklemelerdir. Sarsma tablası deneylerinde yapı veya yapı elemanı istenilen yer hareketi etkisinde incelenmek üzere rijit döşeme üzerine bağlanır. Yapının atalet kuvvetleri ve bunlara karşı gelen tepkiler, dikkate alınabilmektedir. Sarsma tablası kapasitelerindeki sınırlar dolayısı ile genelde küçük ölçekli model numuneler kullanılmaktadır.

Sarsma tablası deneylerinde, yapıların deprem sırasındaki davranışları hakkında çok değerli bilgiler üretilmekle birlikte, deney maliyetleri oldukça yüksektir. Benzerlik/ölçek yasaları kullanılarak oluşturulan ölçekli yapı modelleri daha kısıtlı imkâna sahip sarsma tablaları üzerinde test edilebilmektedir. Bu çalışmada, 15 katlı bir binanın maketi oluşturularak sarsma tablası deneyi ve bilgisayar program analizi ile deprem davranışı incelenmiştir.

\section{2. Çalışmanın Tanıtımı}

Çalışma kapsamında 15 katlı olan ve köşelerinde sadece bir yönde perde bulunan bir yapı modeli ele alınmıştır. Yapının 1/100 ölçekli bir maketi yapılarak sarsma tablasına yerleştirilmiştir. Üç farklı depreme ait mevcut kayıtlı ivme değerleri uygulanarak, ağırlıklı ve ağırlıksız olarak yapının dinamik karakteristikleri elde edilmeye çalışılmıştır. Oluşturulan maketin en üst katına ivme-ölçer yerleştirmek suretiyle çatı ivme değeri ile yerdeğiştirme değeri hesaplanmıştır. Deneysel çalışmanın yanı sıra, yapı Sap2000 programında modellenerek Zaman Tanım Alanında Hesap Yöntemi kullanılarak, yapının dinamik analizleri yapılmıştır. Çalışmanın sonuç kısmında, Sap2000 programı ile gerçekleştirilen sayısal analiz sonuçları ile deneysel çalışmadan elde edilen sonuçlar; ivme, hız ve yer değiştirme değeri bakımından birbirleri ile mukayese edilmiştir.

\subsection{Yapı Sistemi}

İncelenen yapı 15 katlı olup, kat yükseklikleri 5 m'dir. Yapı, planda X - X yönünde ve Y-Y yönünde dörder adet akstan oluşmaktadır. Yapının planda oturma alanı $30 \mathrm{~m}$ x $30 \mathrm{~m}=900 \mathrm{~m}^{2}$ olup, akslar arasındaki mesafe $10 \mathrm{~m}$ olarak belirlenmiştir. Yapının planı Şekil 1'de, kesiti ise Şekil 2'de verilmiştir. Kullanım amacı işyeri olarak planlanan yapının köşelerinde ve sadece tek yönde yerleştirilmiş perdeler bulunmaktadır. Yapının geriye kalan taşıyıcı elemanları kolonlardan ve çerçeve kirişlerinden oluşmaktadır. Kolon, kiriş ve perde elemanlarının boyutları aşağıdaki tabloda (Tablo 1) verilmiştir. 


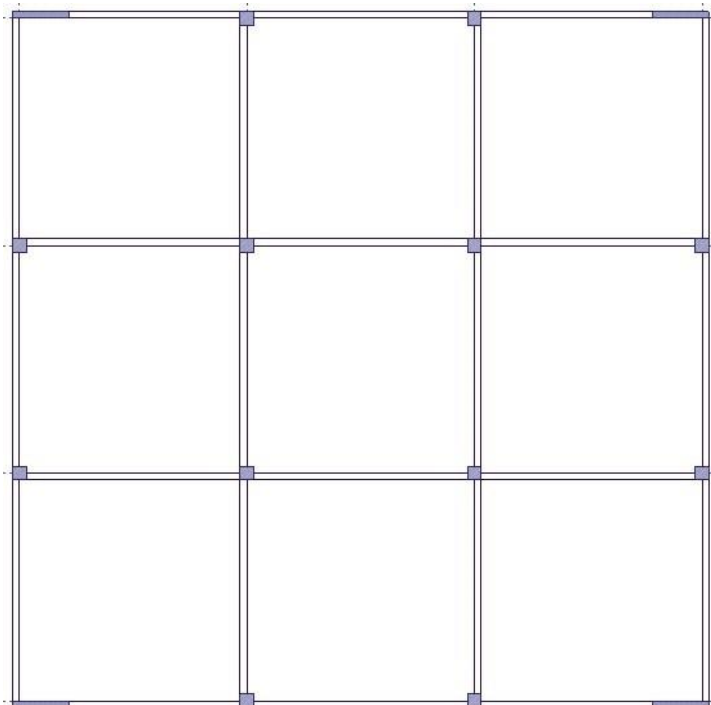

Şekil 1. Yapı Planı

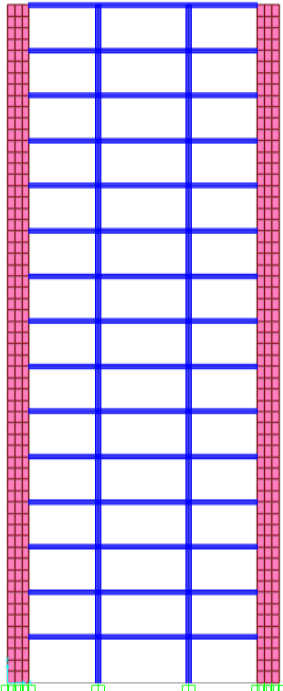

Şekil 2. Kesit

Tablo 1. Taşıyıcı Elemanlar ve Boyutları

\begin{tabular}{|l|c|c|c|}
\hline Yapı Elemanı & $\begin{array}{c}\text { Kısa Kenarı } \\
(\mathbf{m m})\end{array}$ & $\begin{array}{c}\text { Uzun Kenarı } \\
(\mathbf{m m})\end{array}$ & $\begin{array}{c}\text { Kesit Alanı } \\
\mathbf{( ~ m m ~}^{\mathbf{2}} \mathbf{~}\end{array}$ \\
\hline Perde & 300 & 2400 & 720000 \\
\hline Kolon & 600 & 600 & 360000 \\
\hline Kiriş & 300 & 500 & 150000 \\
\hline
\end{tabular}

\subsection{Yapı Maketi ve Kullanılan Malzemeler}

İncelenen yapının 1/100 ölçeğinde maketi yapılmıştı. Maket yapıda; kolon ve kiriş elemanlarının malzemesi kavak ağacından, perde elemanlarının malzemesi ise huş ağacından oluşmaktadır. Elemanlar bu malzemelerden üretilmiş olan çıtalar ve levhalar kullanılarak inşa edilmiştir.

Kavak ağacı, Türkiye'nin her yerinde yetişen ve uygun koşullarda çabuk büyüyen bir ağaçtır. Kavak ağacının gövdesinin tümü dış odun özelliği gösterir. Bütün kavak türleri dağınık gözeneklidir. Gözenekleri ve öz ışınları çıplak gözle görünmez. Kavak ağacı çok yumuşak, kaba ve gevşek yapılıdır. Uygun koşullarda az çalışır, az çatlar, kolay kesilir. Tutkalla iyi bağlantı kurar. Fizik etkilerine dayanımı zayıftır. Hava kurusu kavağın özgül ağırlığı $0.45 \mathrm{gr} / \mathrm{cm}^{3}$ ‘ürr.

Huş ağacı ise; ülkemizde Doğu Karadeniz ve Doğu Anadolu Bölgelerinde yetişir ve kayın veya süpürge ağacı olarak isimlendirilir. Olgun ağaçlar grubuna girer. Dağınık gözeneklidir. Uzun iplikli ve düzgün yapılıdır. Sıkı ve ince yapılıdır. Orta sert bir ağaçtır. Bükülgendir. Fizik etkilerine dayanımı iyidir. Zor yarılır. Tutkalla iyi yapışır. Çok iyi boya ve vernik tutar. Hava kurusu özgül ağırlığı $0.62 \mathrm{gr} / \mathrm{cm}^{3}$ tür.

Maket yapının taşıyıcı elemanlarının teşkilinde kullanılan kavak ağacı malzemesinin ve huş ağacı malzemesinin mekanik özellikleri Tablo 2'de verilmiştir.

Tablo 2. Maket Yapıda Taşıyıcı Elemanların Mekanik Özellikleri

\begin{tabular}{|l|c|c|c|c|}
\hline Yapı Elemanı & Malzeme & $\begin{array}{c}\text { Ağırlık Birimi } \\
\left(\mathbf{~ k N} / \mathbf{m}^{\mathbf{3}}\right)\end{array}$ & $\begin{array}{c}\text { Birim Kütle } \\
\left(\mathbf{~ k N . s 2} / \mathbf{m}^{\mathbf{4}}\right)\end{array}$ & $\begin{array}{c}\text { Elastisite Modülü } \\
\left(\mathbf{~ k N} / \mathbf{m}^{2}\right)\end{array}$ \\
\hline Perde & Huş & 9,2477 & 0,943 & 7050000 \\
\hline Kolon - Kiriş & Kavak & 6,5214 & 0,665 & 6800000 \\
\hline
\end{tabular}

Maketi oluşturan elemanların birbirine rijit olarak bağlanmasını sağlamak amacıyla Pattex marka, 2k profesyonel hızlı yapıştırıcı ve aktivatör kullanılmıştır. Elemanların yüzeyleri temizlenip, yağdan ve tozdan arındırıldıktan sonra yapıştırıcı uygulanmıştır. Uygulamada kullanılan yapıştırıcı sayesinde elemanların birleştiği yüzeyler arasında tam penetrasyon sağlanmıştır. Deneylerde yapıştırıcının birleştirdiği bağlantı noktalarında kopma meydana gelmemiş olup, yapıştırıcıdan beklenen performansın sağlandığı sonucuna varılmıştır.

Maket yapıda kullanılan malzemelerin miktarı ve ağırlıkları Tablo 3’te verilmiştir. 
Tablo 3. Maket Yapıda Kullanılan Elemanların Miktarları ve Ağırlkkları

\begin{tabular}{|l|c|c|c|c|}
\hline Yapı Elemanı & Nesne & Adedi & $\begin{array}{c}\text { Toplam Uzunluk } \\
(\mathbf{~ m ~})\end{array}$ & $\begin{array}{c}\text { Toplam Ă̆ırlık } \\
(\mathbf{~ k g})\end{array}$ \\
\hline Perde & Levha & 360 & 34,56 & 3,3810 \\
\hline Kolon & Çıta & 180 & 9,00 & 2,1130 \\
\hline Kiriş & Çıta & 4 & 3,00 & 1,9970 \\
\hline Tavan Plakası & Levha & 1 & & 0,5217 \\
\hline
\end{tabular}

Model yapı, $300 \mathrm{~mm}$ x $300 \mathrm{~mm}$ taban alanına sahip olup, $750 \mathrm{~mm}$ yüksekliğinde ve 15 katlı bir işyeri olarak planlanmıştır. Planda simetrik olarak tasarlanan yapının planı yapının yüksekliği boyunca değişmemektedir. Yapının taşıyıcı elemanlarının boyutları da, yapı yüksekliği boyunca değiştirilmemiştir. Toplam model yapı ağırlığı $8,013 \mathrm{~kg}$ olarak ölçülmüştür.

\subsection{Deney Düzeneği}

Çalışma kapsamında üretilen yapı maketi, küçük ölçekli sarsma masasında ağırlıklı ve ağırlıksız test edilmiştir. Sarsma tablasına yerleştirilen yapı modeli, harmonik harekete maruz bırakılmıştır. Harmonik hareketinin frekansı kademeli olarak artırılarak üç farklı yer hareketi verilmiş, çok katlı yapı maketinde saniyelik ivme kaydı alınmıştır. Deney aşamasında resim ve video kayıtları alınmıştır. Yapıya ait test sonuçları, gerçekleştirilen sayısal model sonuçları (Sap2000 analizi) ile karşılaştırılmıştır. 1/100 ölçekli yapısal model dinamik deneyleri için sarsma tablası ve çevre birimleri deney düzeneği olarak kullanılmıştır.

Maket yapı ahşap rijit bir taban plakası üzerine ankastre olacak şekilde sarsma tablasına sabitlenmiştir. Maket yapının sınır şartlarını sağlanması için ahşap elemanlar ve bulonlar kullanılmıştır. Taban plakasının etrafı ahşap rijit bloklar yardımıyla çevrilmiş ve ahşap bloklar sarsma tablasına civatalar kullanılarak ankastre mesnetli olarak bağlanmıştır (Şekil 3).
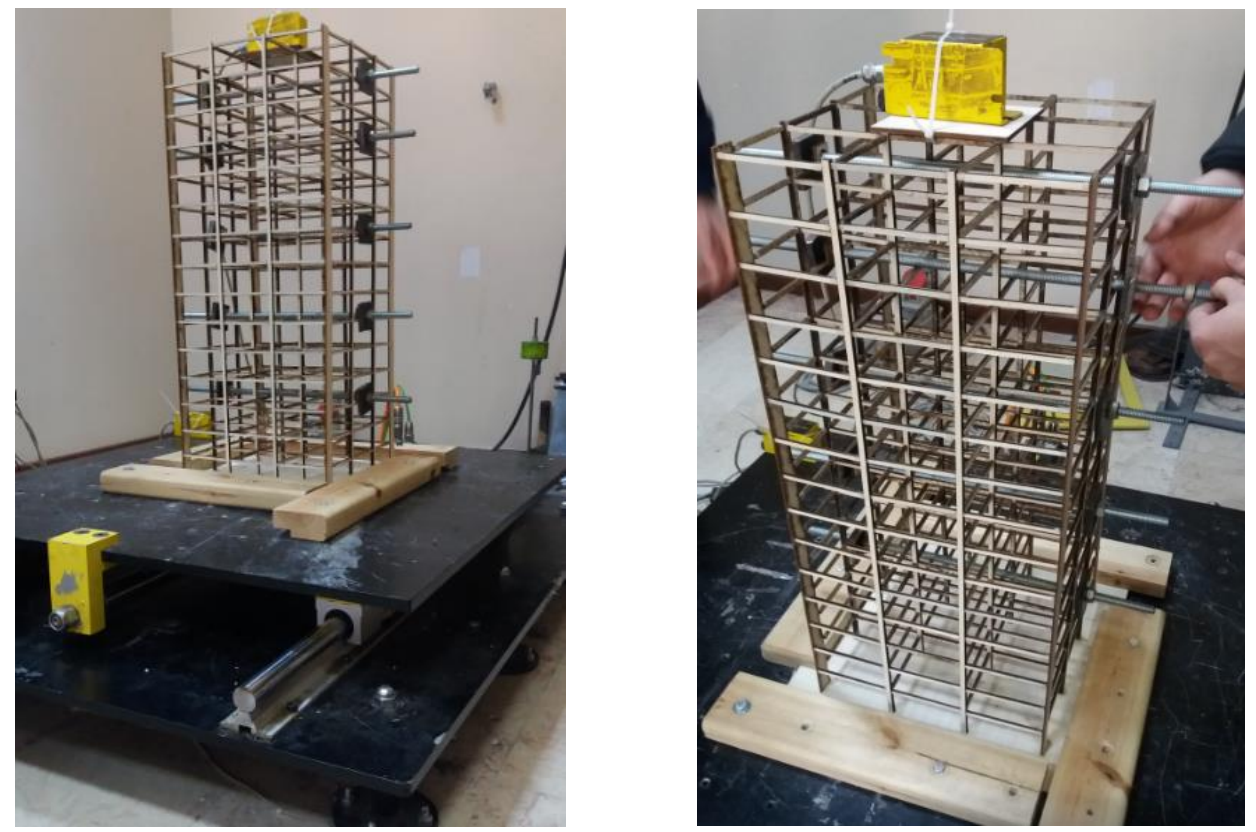

Şekil 3. Maket Yapının Sarsma Tablasına Yerleştirilmesi

Sarsma tablası $1 \mathrm{~m}$ x1 m boyutundadır. Kapasitesi $125 \mathrm{~kg}$ 'dır. Maksimum yatay kuvvet kapasitesi $2500 \mathrm{~N}$, toplam hareket boyu $\pm 100 \mathrm{~mm}$, maksimum ivme kapasitesi $\pm 2 \mathrm{~g}$ ve maksimum doğrusal hızı $500 \mathrm{~mm} / \mathrm{s}$ olarak belirlenmiştir. Söz konusu sarsma tablası ile 1 $\mathrm{Hz}$ ile $10 \mathrm{~Hz}$ arasında sinüzoidal yük uygulanabilmektedir. Ayrıca, Sakarya ve El-Centro gibi deprem kayıtlarının uygulanması da mümkündür. Sarsma tablası, sensörler ile dinamik veri toplayıcı cihazı yardımıyla veri işlemek için masaüstü computer deney düzeneğinde kullanılan çevre birimleridir. Ayrıca, $0-1200 \mathrm{~Hz}$ frekans aralı̆̆ında ivme-ölçerlerden yararlanılmıştır. Dinamik veri toplayıcısı, sensörlerden aldığı kayıtları sayısal değerlere dönüştürerek sinyal işleme yazılımına aktarmaktadır. Sensebox 7021/7022/7023+ ve 7031/7032/7033 ivme-ölçerler kullanılarak titreşimler ölçülmektedir. Oldukça düşük gürültülü sensörler olan bu ivmeölçerler, kuvvet/elektro-dinamik geri beslemelidir. Mikro elektromekanik sistem (MEMS) şahit olarak kullanılan ivme-ölçerlerdir. $\mathrm{Bu}$ ivme-ölçerlerin sensörü, mikroçip tabanlıdır ve teknolojisi mikro-mekanik ölçekte kuvvet geri beslemelidir. $\pm 3 \mathrm{~g}$ ölçüm kapasiteli olan ivme-ölçerlerin gürülttü performansı 5 mikro-g/Hz'dir. İvme-ölçerlerin frekans aralığı 0-400 Hz olarak belirlenmiştir. Bu ivmeölçerler yüksek çözünürlüklü ve düşük gürültülüdür. Bu nedenle; modal analiz, yapı sağlığı takibi ve sismik araştırmalar gibi konularda faydalıdır. Dinamik veri toplama cihazı kullanmak suretiyle, ivme-ölçerlerin okumaları kaydedilebilmektedir. Deneyde kullanılan dinamik sayısallaştırıcının çözünürlüğü 24 Bit’tir. Dinamik aralığı $140 \mathrm{~dB}$ olup eş zamanlı örnekleme yapabilmektedir. 


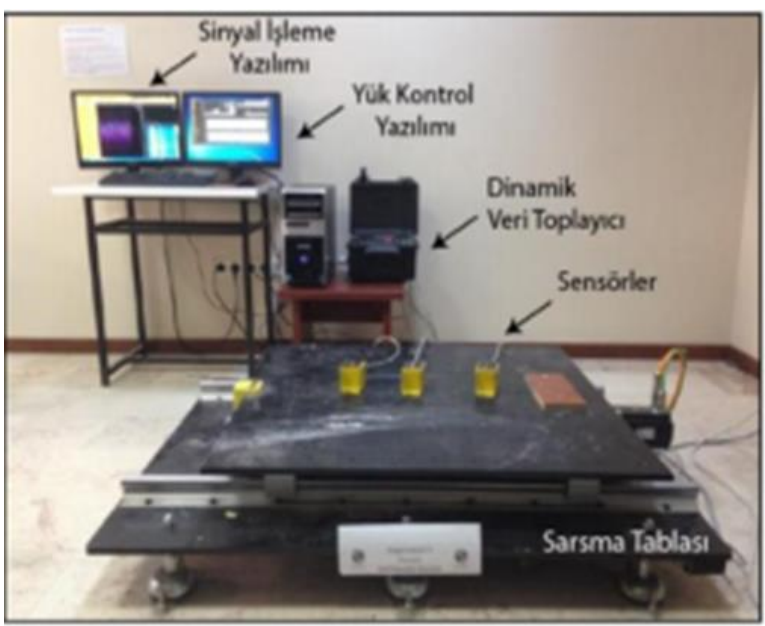

Şekil 4. Deney Düzeneği

\section{Deneysel Çalışma ve Sayısal Analizler}

Çalışma kapsamında üretilen 15 katlı yapı maketi, sarsma tablasında ağırlıklı ve ağırlıksız olarak deneye tabi tutulmuştur. Sarsma tablasına yerleştirilen yapı maketi, harmonik harekete maruz bırakılmıştır. Maket yapının doğal frekansını elde etmek için serbest titreşim uygulanmış olup, SiesmoSignal programı kullanılmak suretiyle belirlenen ivme zaman kayıtları filtrelenmiştir. Diğer taraftan, sarsma tablası yardımıyla maket yapıya uygulanan üç farklı deprem ivme kaydı, Zaman Tanım Alanında Hesap Yöntemi (Time History) kullanılarak yapının dinamik analizleri yapılmıştır. Analizler, SAP2000 programı ile yapının sonlu eleman modeli oluşturulmak suretiyle gerçekleştirilmiştir.

\subsection{Deneysel Çalışma}

İncelenen 15 katlı ve köşelerinde sadece bir yönde perde bulunan yapının 1/100 ölçekli olarak üretilen maketi, sarsma tablasına yerleştirilmiştir. Harmonik hareketinin frekansı kademeli olarak artırılarak üç farklı yer hareketi verilmiş, çok katlı yapı maketinde saniyelik ivme kayıtları alınmıştır. Ayrıca, maketin en üst katına ivme-ölçer yerleştirmek suretiyle çatı ivme değeri ile yerdeğiştirme değeri hesaplanmıştır.

Maket yapıda sabit ve hareketli yükü temsil etmesi için, her üç katta bir, yapıya 1,5 kg'lık ağırlıklar eklenerek toplu kütleli sistem davranışı elde edilmeye çalışılmıştır. 1,5 kg’lık ağırlık belirlenirken, yapının kullanım amacı ve geometrisi dikkate alınmıştır. Ayrıca çalışmada kat ağırlıklarının sonuca etkisini en aza indirmek için farklı deprem yüklerinin uygulandığ üç farklı deneysel çalışmada 1,5 kg'lık ağırlık, yapıda aynı kata ve aynı noktaya uygulanmıştır.

YH1, YH2 ve YH3 olarak adlandırılan üç farklı depreme ait mevcut kayıtlı ivme değerleri uygulanarak, yer hareketleri yap1 maketine perdelerin uzun doğrultusunda verilmiştir. Bina ağırlıkları üç katta bir olmak üzere depreme dik doğrultuda kirişlerin üzerine sabitlenmiştir. Böylelikle her bir yer hareketine karşılık üç ağırlıklı (dolu), üç ağırlıksız (boş) toplam altı deney yapılmıştır. Bina toplam ağırlığı 801,27gr olup bağlanan ağırlıkların her biri 1,5 kg'dır.

Maket yapının dinamik davranışının belirlenmesi için uygulanan üç farklı depreme ait ivme-zaman kayıtları Şekil 5, Şekil 6 ve Şekil 7'de gösterilmiştir.

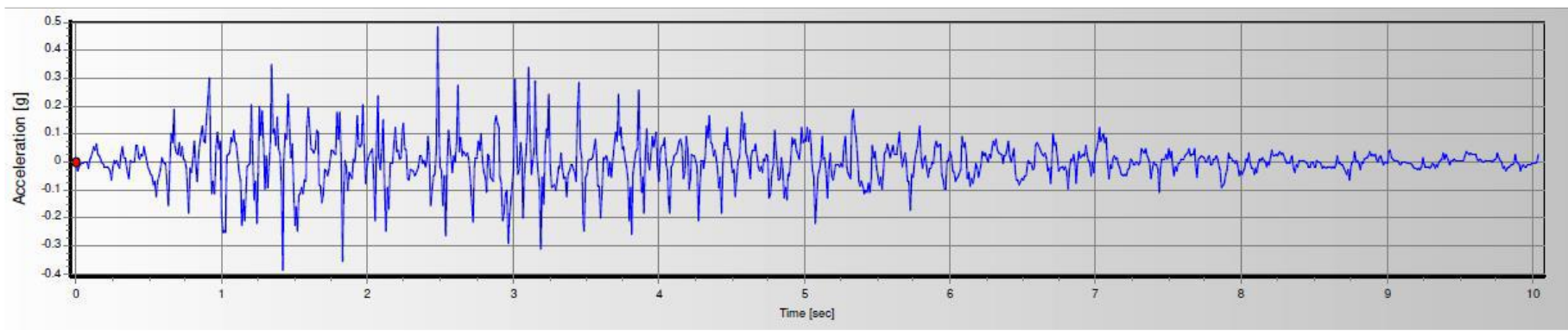

Şekil 5. Deprem 1'e (YH1) Ait ivme-zaman kayıtları 


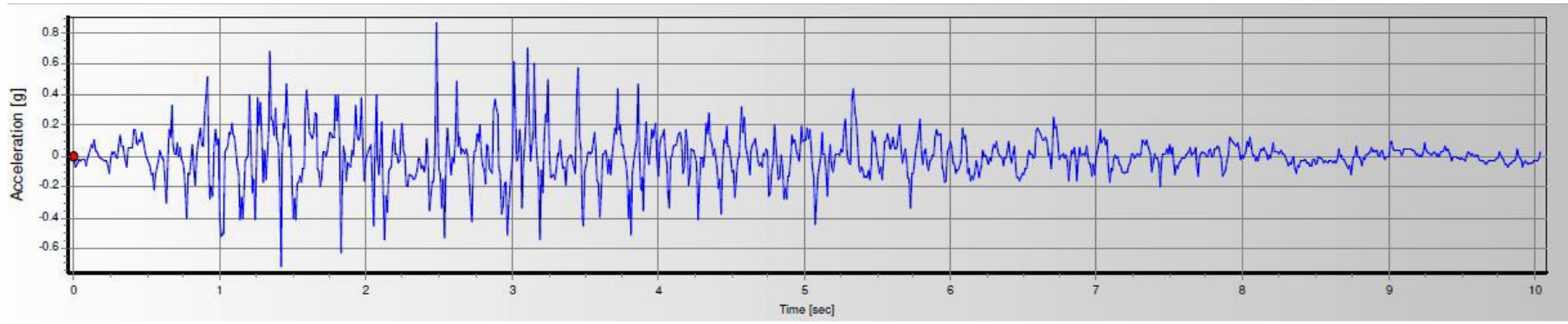

Şekil 6. Deprem 2’ye (YH2) Ait ivme-zaman kayıtları

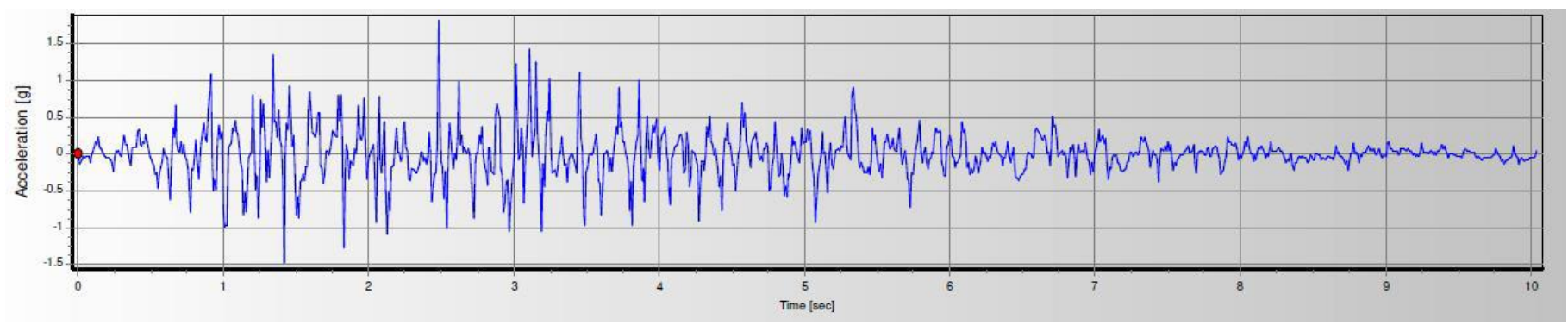

Şekil 7. Deprem 3'e (YH3) Ait ivme-zaman kayıtları

Sarsma tablasına bağlı bulunan veri toplama sisteminde yer alan veri filtreleme algoritması ile deney esnasinda ortamda bulunan gürültü filtrelenmektedir. Butterwort filtreleme işlemi $1,5-15 \mathrm{~Hz}$ arasındaki verileri filtrelemekte olup, deneylerde veri toplama sisteminde kullanılmıştır.

Fourier dönüşümü kullanmak suretiyle ivme-ölçerlerden alınan ivme-zaman değerleri, frekansın bir fonksiyonuna dönüştürülmüştür. Grafiklerdeki maksimum değerler doğal titreşim frekansını vermektedir. SiesmoSignal programı marifetiyle, Fourier dönüşümünden yararlanılarak yapının doğal titreşim frekansı belirlenmiş̧ir. Deneylerden elde edilen ivme kayıtları SiesmoSignal 2018 programı kullanılarak filtre edilmiştir.

Hazırlanan yapı maketine ağıllıksız (boş) olarak uygulanan üç farklı yer hareketi ile (YH1, YH2 ve YH3) yapılan deneysel çalışma sonucunda elde edilen tepe noktası ivme-zaman, hız-zaman ve yerdeğiştirme-zaman grafikleri; sırasıyla Şekil 8, Şekil 9 ve Şekil 10'da verilmiştir.
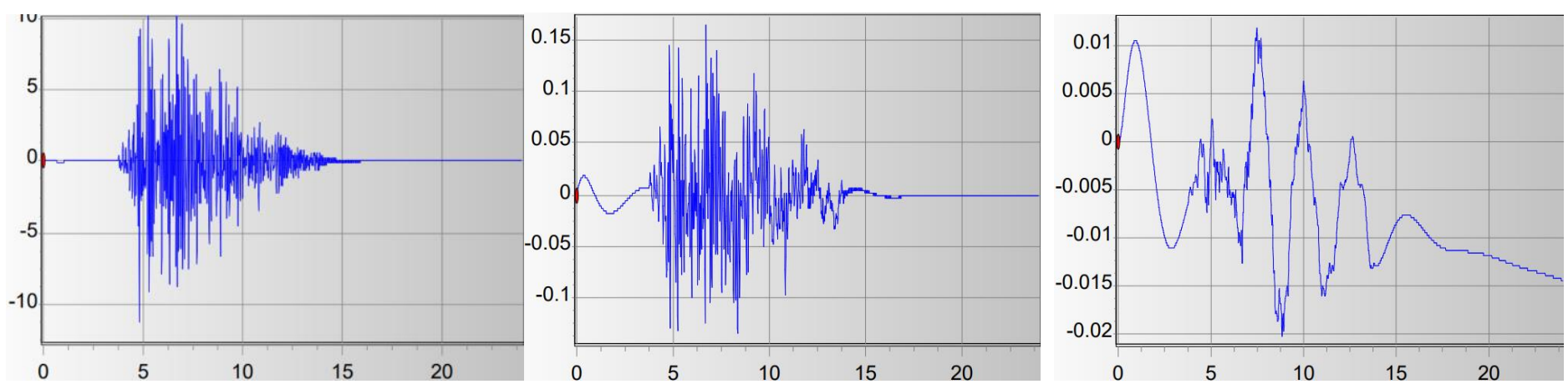

Şekil 8. Ağırlıksız Olarak Deprem 1'e (YH1) Ait Grafikler
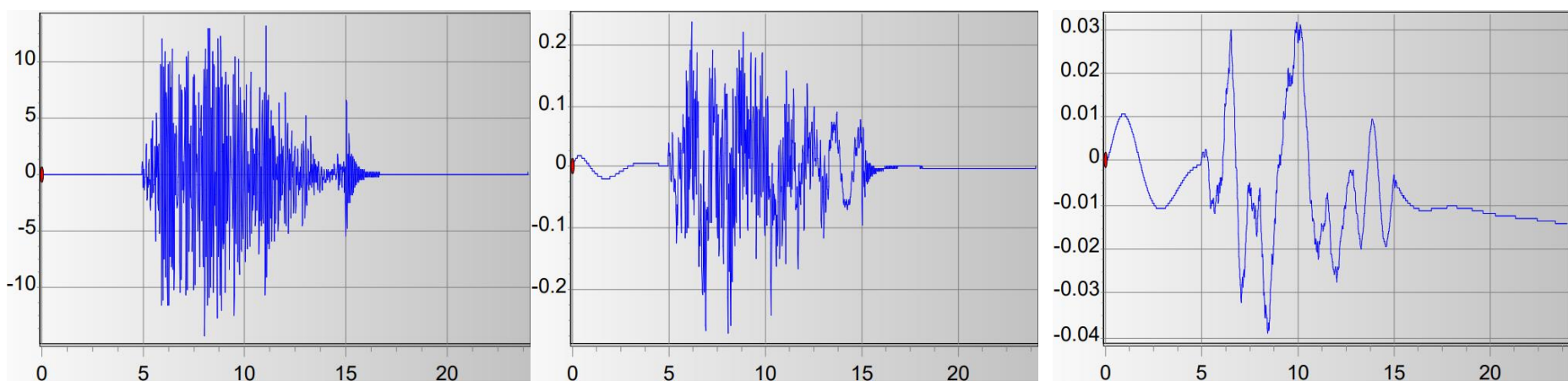

Şekil 9. A ğırlıksız Olarak Deprem 2’ye (YH2) Ait Grafikler 
European Journal of Science and Technology
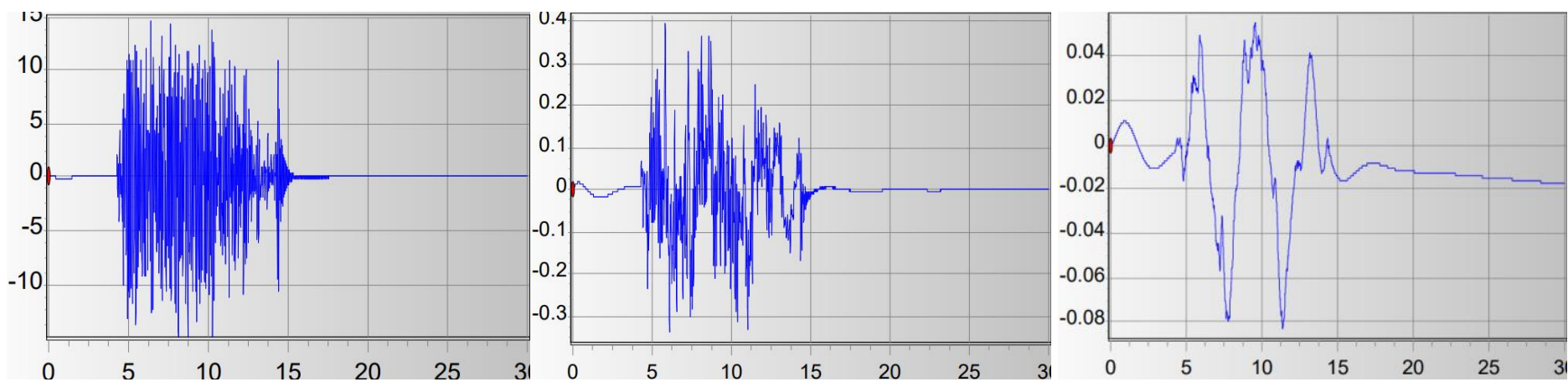

Şekil 10. Ağırlıksız Olarak Deprem 3'e (YH3) Ait Grafikler

Daha sonra, aynı makete ağırlıklı (dolu) olarak ve yine aynı üç farklı yer hareketi (YH1, YH2 ve YH3) uygulamak suretiyle yapılan deneysel çalışma sonucunda elde edilen tepe noktası ivme-zaman, hız-zaman ve yerdeğiştirme-zaman grafikleri ise; sırasıyla Şekil 11, Şekil 12 ve Şekil 13'de verilmiştir.
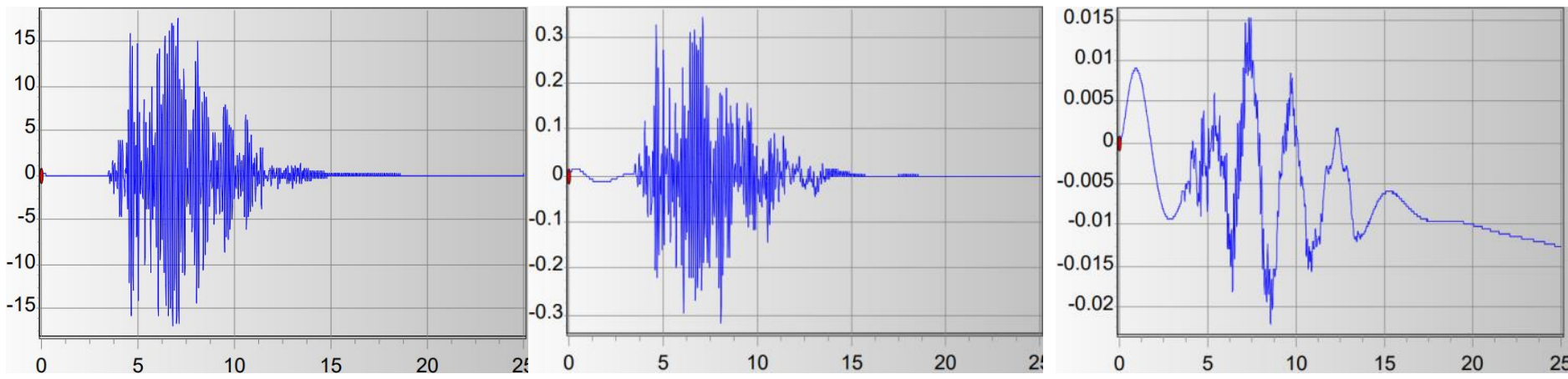

Şekil 11. Ağırlıklı Olarak Deprem 1'e (YH1) Ait Grafikler
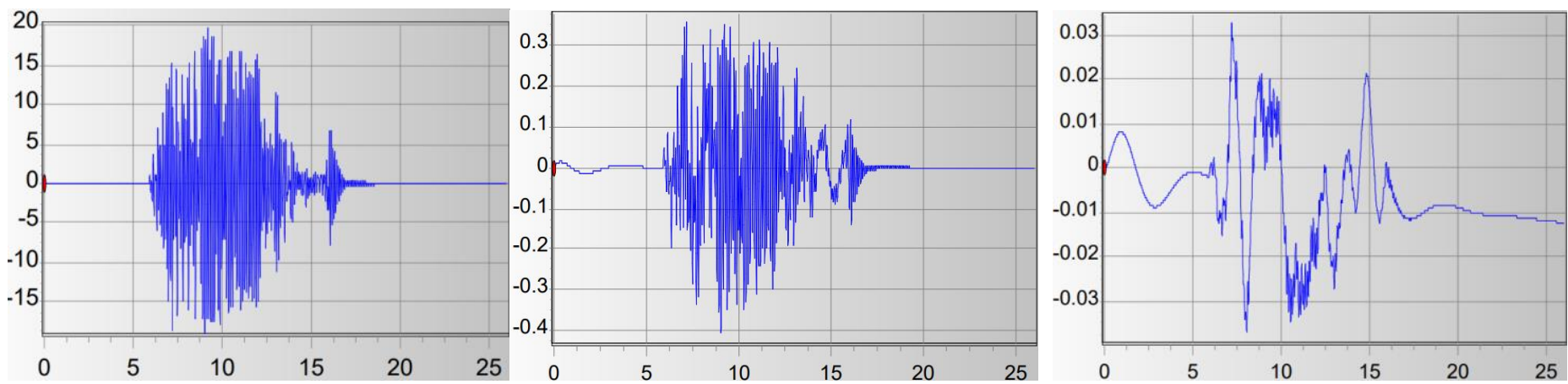

Şekil 12. Ağırlıklı Olarak Deprem 2’ye (YH2) Ait Grafikler
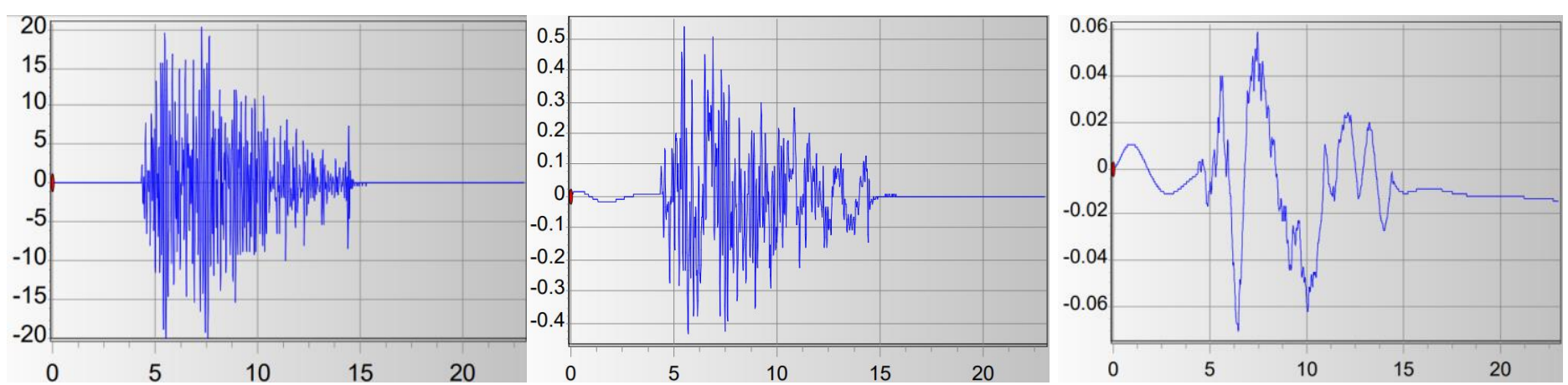

Şekil 13. Ağırlıklı Olarak Deprem 3’e (YH3) Ait Grafikler 


\subsection{Sayısal Analiz}

İncelenen 15 katlı ve köşelerinde sadece bir yönde perde bulunan yapı Sap2000 programında modellenmiş ve Zaman Tanım Alanında Hesap Yöntemi kullanılarak, yapının dinamik analizleri yapılmışıı (Şekil 14).

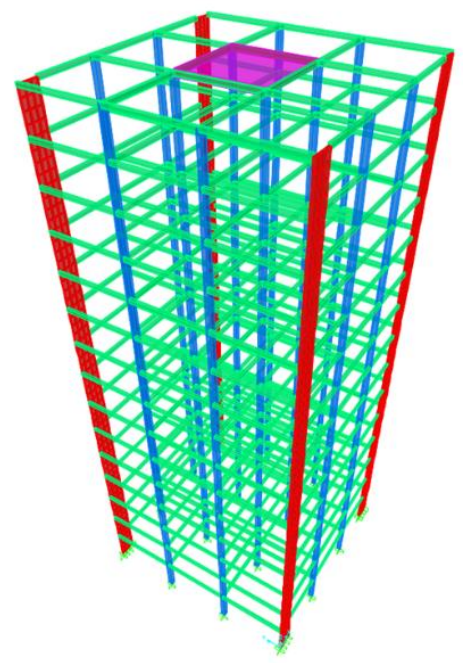

Şekil 14. İncelenen Yapının Sap2000 Programında Üç Boyutlu Modeli

Sap2000 programı ile yapının kolon ve kiriş elemanları çubuk eleman (frame eleman) olarak modellenmiş, döşeme için ise rijit diyafram kabulü yapılmıştır. Rijit diyafram kabulünün gerekçesi, döşeme rijitliğinin düşey taşıyıcı sistem elemanlarının rijitliğine göre çok daha büyük olmasıdır. Deneysel çalışmada her üç katta bir yerleştirilen $1,5 \mathrm{~kg}$ ağıllık ile tanımlanan ve rijit diyafram tanımında gerekli olan kütle değeri, sonlu eleman modeline de yansıtılmıştır. Perdeler kabuk (Shell) elemanı olarak modellenmiştir. Maket yapı, rijit ahşap bloklar ve bulonlar yardımıyla sarsma tablasına monte edilmiş, bu sayede Sap2000 programında yapılan sonlu eleman modelde ankastre sınır şartı olarak tanımlanmıştır. Sarsma tablası deneyinde ağırlıklı ve ağırlıksız olarak model yapıya uygulanan üç farklı deprem ivme kaydı kullanarak SAP2000 programı ile Zaman Tanım Alanında Hesap Yöntemi (Time History) ile ayrı ayrı analizler yapılmıştır.

Zaman Tanım Alanında Doğrusal Olmayan Hesap Yönteminin kullanılmasının amacı, taşıyıcı sistemdeki doğrusal olmayan davranışını göz önünde bulundurarak sistemin hareket denklemini adım adım entegre etmektir. Analiz sırasında her bir zaman artımında sistemde meydana gelen yer değiştirme, plastik şekil değiştirme ve iç kuvvetler ile bu büyüklüklerin deprem istemine karşı gelen maksimum değerleri hesaplanmıştır. Zaman tanım alanında yapılacak analizde kullanılacak yapay, kaydedilmiş veya benzeştirilmiş yer hareketleri belirlenerek, analizde göz önüne alınmıştır.

Sap2000 programında yapının ağırlıksız (boş) durumu için uygulanan üç farklı yer hareketi ile (YH1, YH2 ve YH3) yapılan analizleri sonucunda elde edilen tepe noktası ivme-zaman, hız-zaman ve yerdeğiştirme-zaman grafikleri; ssrasıyla Şekil 15, Şekil 16 ve Şekil 17'de verilmiştir.
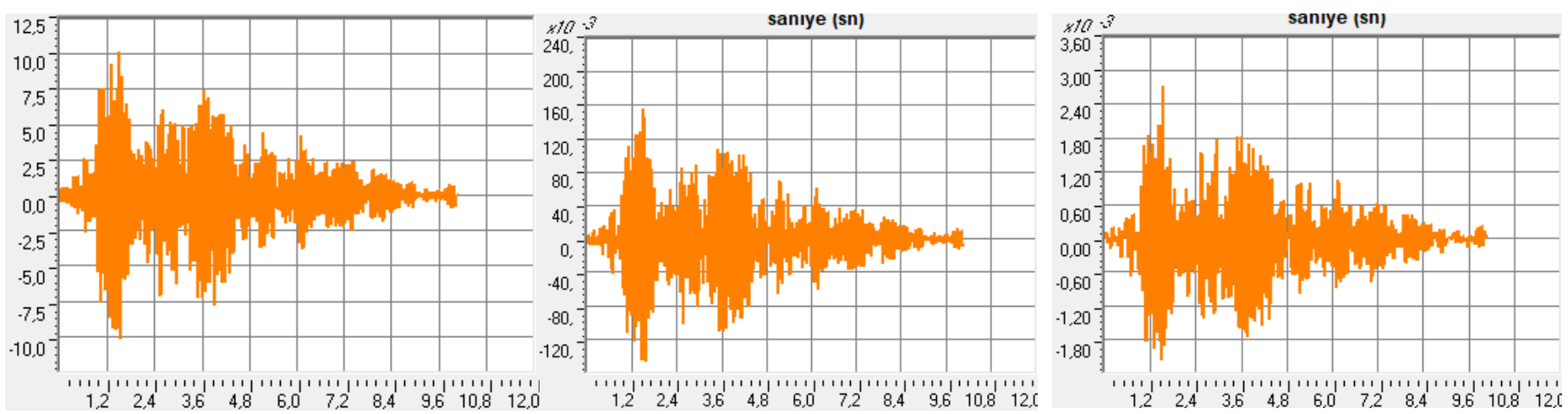

Şekil 15. Ağırlıksız Olarak Deprem 1'e (YH1) Ait Grafikler 
European Journal of Science and Technology
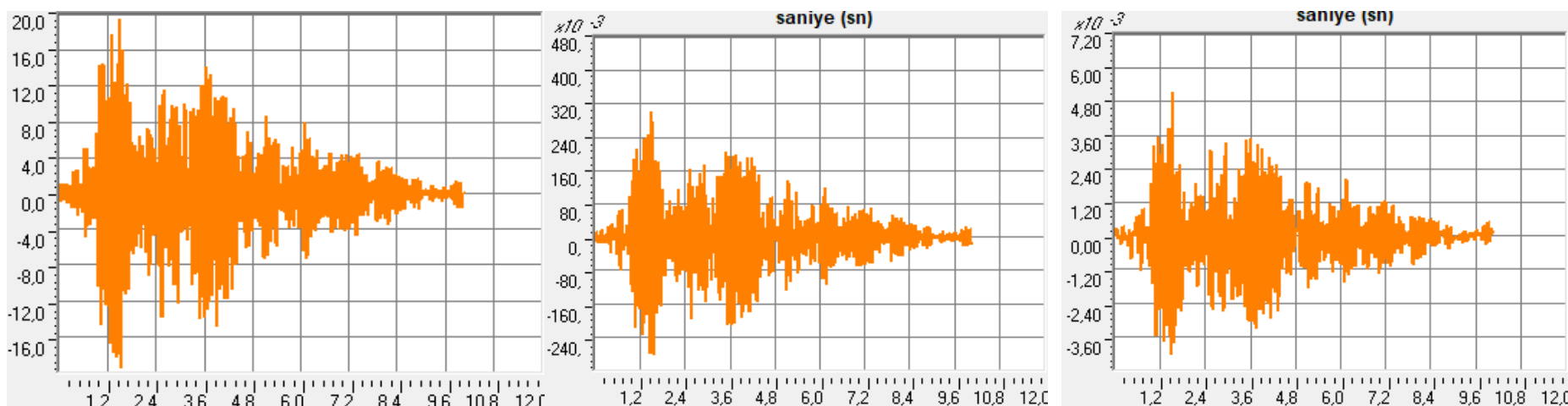

Şekil 16. Ağılıksız Olarak Deprem 2’ye (YH2) Ait Grafikler
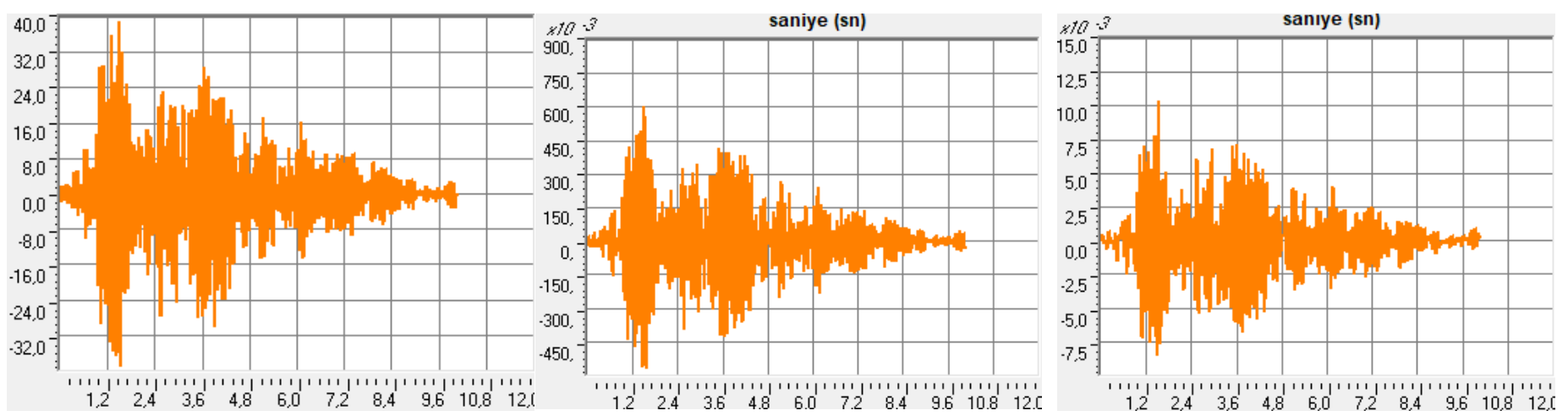

Şekil 17. Ağırlıksız Olarak Deprem 3'e (YH3) Ait Grafikler

Sap2000 programında yapının ağırlıklı (dolu) durumu için uygulanan yine aynı üç farklı yer hareketi ile (YH1, YH2 ve YH3) yapılan analizleri sonucunda elde edilen tepe noktası ivme-zaman, hız-zaman ve yerdeğiştirme-zaman grafikleri ise; sırasıyla Şekil 18, Şekil 19 ve Şekil 20'de verilmiştir.
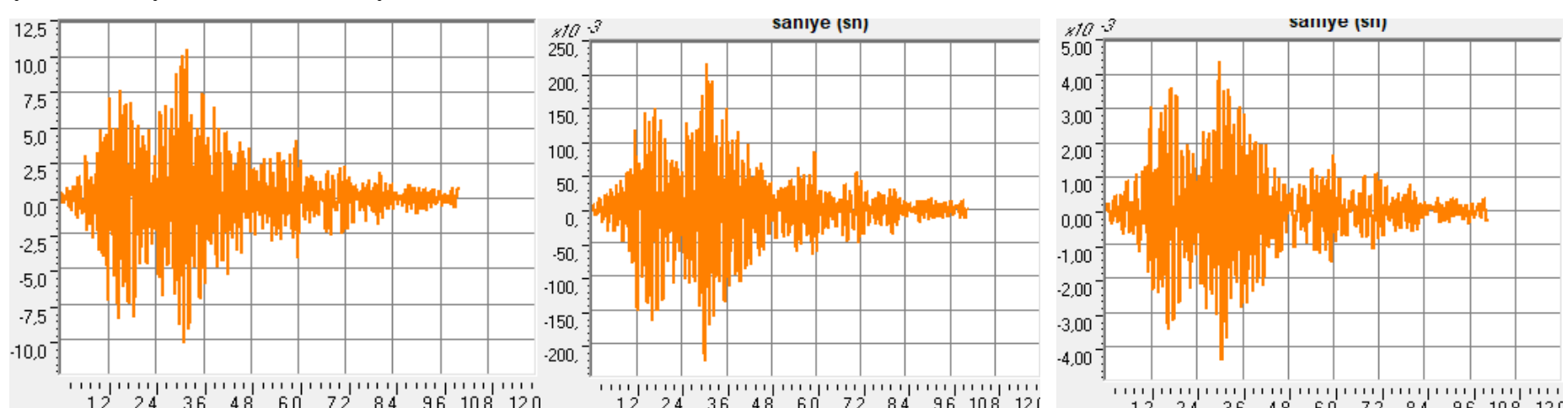

Şekil 18. Ağırlıklı Olarak Deprem 1'e (YH1) Ait Grafikler
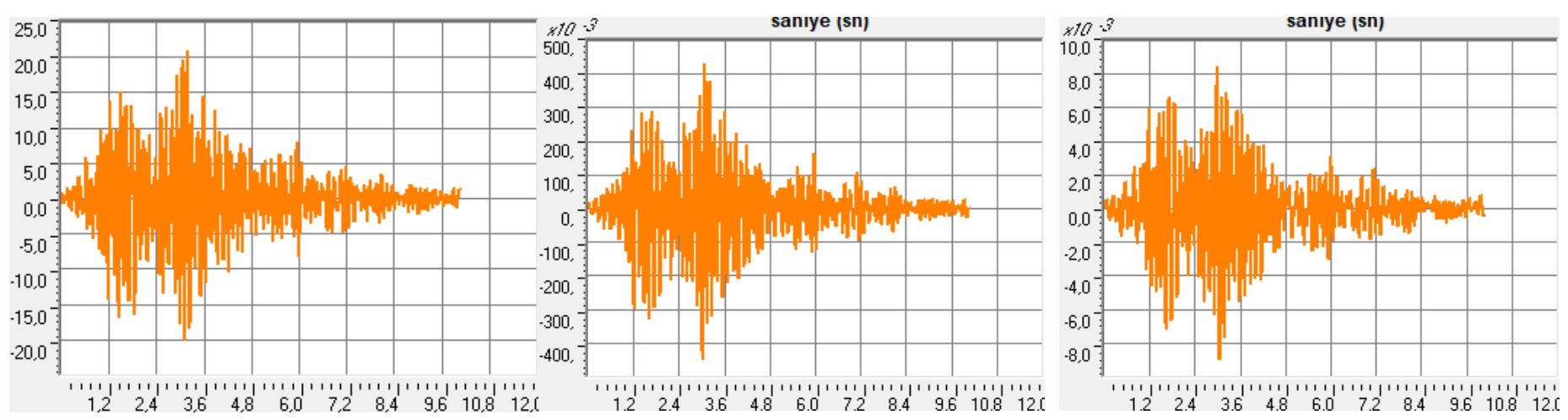

Şekil 19. Ağırlıklı Olarak Deprem 2'ye (YH2) Ait Grafikler 

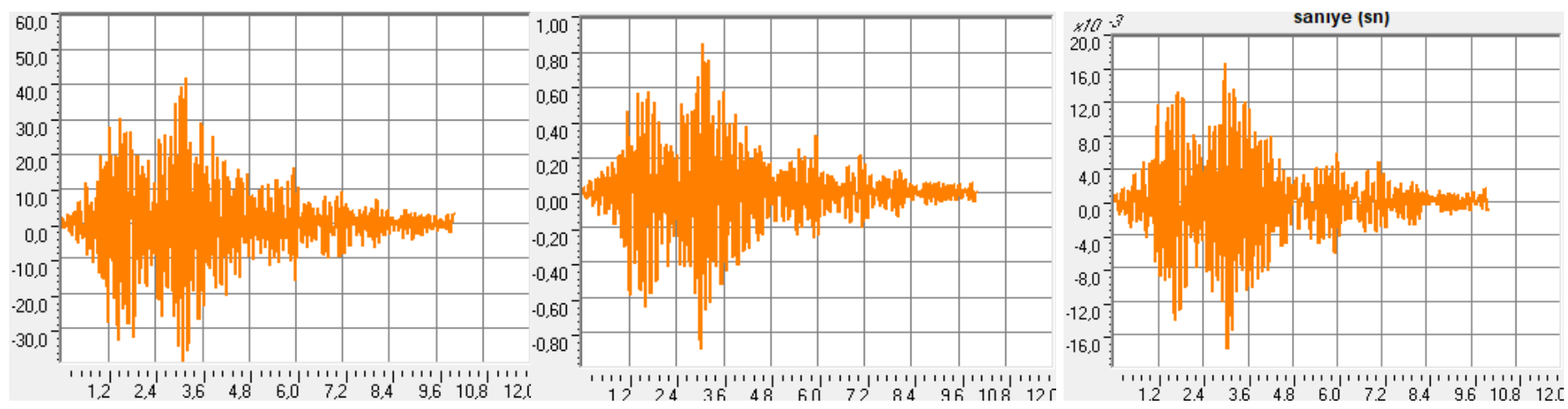

Şekil 20. Ağırlıklı Olarak Deprem 3’e (YH3) Ait Grafikler

\section{Sonuçlar}

Çalışma kapsamında üretilen 15 katlı yapı maketi, sarsma tablasında ağılıklı ve ağılıksız olarak teste tabi tutulmuştur. Sarsma tablasına yerleştirilen yapı maketi, harmonik harekete maruz bırakılmıştır. Maket yapının doğal frekansını elde etmek için serbest titreşim uygulanmış olup, SiesmoSignal programı kullanılmak suretiyle belirlenen ivme zaman kayıtları filtrelenmiştir. Diğer taraftan, sarsma tablası yardımıyla maket yapıya uygulanan üç farklı deprem ivme kaydı, Zaman Tanım Alanında Hesap Yöntemi (Time History) kullanılarak yapının dinamik analizleri yapılmışır. Analizler, SAP2000 programı ile yapının sonlu eleman modeli oluşturulmak suretiyle gerçekleştirilmiştir.

Bu çalışmada 15 katlı olan ve köşelerinde bir yönde perdeli olan bir yapının deneysel ve analitik olarak elde edilen dinamik karakteristikleri karşılaş̧ırılmıştır. Sarsma tablası ile deprem yüklerine maruz bırakılan model yapıdan ivme-ölçerler yardımı ile alınan okumalar Sismosignal programı ile işlenmiştir. Yapı maketine kayıtlı deprem ivme kayıtları uygulanarak tepe noktası ivme değerleri elde edilmiş̧ir. Diğger taraftan Sap2000 programı vasıtasıyla, deneysel çalışmadaki sınır koşullara uygun olarak yapı üç boyutlu olarak modellenmiştir. Sap2000 analizlerinde ve sarsma tablası deneylerinde aynı üç farklı deprem yüklemesi yapılarak, Zaman Tanım Alanında Hesap yöntemi ile sayısal analizlerde tepe noktası ivme-zaman, hız-zaman ve yer değiştirme-zaman grafikleri çizilmiş̧ir.

Yapının ağırlıksız (boş) ve ağırlıklı (dolu) durumları için; Sap2000 programı ile gerçekleştirilen sayısal analiz sonuçları ile deneysel çalışmadan elde edilen sonuçlar aşağıdaki tablolarda (Tablo 4 ve Tablo 5) karşılaştırılmıştır:

Tablo 4. Ăgırlıksız Olarak Yapının Deneysel ve Sayısal Analiz Sonuçlarının Karşılaştıılması

\begin{tabular}{|l|l|l|l|}
\hline \multirow{4}{*}{ Yer Hareketi 1} & Deneysel Sonuçlar & SAP2000 Analizi Sonuçları \\
\cline { 2 - 4 } & Periyot & $0.08 \mathrm{~s}$ & $0.109541 \mathrm{~s}$ \\
\cline { 2 - 4 } & Maksimum İvme & $11.475 \mathrm{~m} / \mathrm{s}^{2}, \mathrm{t}=5.260 \mathrm{~s}$ & $10.11 \mathrm{~m} / \mathrm{s}^{2}, \mathrm{t}=1.493 \mathrm{~s}$ \\
\cline { 2 - 4 } & Maksimum Hız & $0.165 \mathrm{~m} / \mathrm{s}, \mathrm{t}=6.710 \mathrm{~s}$ & $0.1562 \mathrm{~m} / \mathrm{s}, \mathrm{t}=1.513 \mathrm{~s}$ \\
\cline { 2 - 4 } & Maksimum Yer Değiştirme & $0.020 \mathrm{~m}, \mathrm{t}=8.840 \mathrm{~s}$ & $0.027 \mathrm{~m}, \mathrm{t}=1.537 \mathrm{~s}$ \\
\hline \multirow{4}{*}{ Yer Hareketi 2} & $0.08 \mathrm{~s}$ & $0.109541 \mathrm{~s}$ \\
\cline { 2 - 4 } & Periyot & $14.293 \mathrm{~m} / \mathrm{s}^{2}, \mathrm{t}=8.030 \mathrm{~s}$ & $19.48 \mathrm{~m} / \mathrm{s}^{2}, \mathrm{t}=1.535 \mathrm{~s}$ \\
\cline { 2 - 4 } & Maksimum İvme & $0.270 \mathrm{~m} / \mathrm{s}, \mathrm{t}=8.050 \mathrm{~s}$ & $0.3 \mathrm{~m} / \mathrm{s}, \mathrm{t}=1.512 \mathrm{~s}$ \\
\cline { 2 - 4 } & Maksimum Hız & $0.039 \mathrm{~m}, \mathrm{t}=8.420 \mathrm{~s}$ & $0.0513 \mathrm{~m}, \mathrm{t}=1.537 \mathrm{~s}$ \\
\hline \multirow{3}{*}{ Yer Hareketimum Yer Değiştirme 3} & $0.08 \mathrm{~s}$ & $0.109541 \mathrm{~s}$ \\
\cline { 2 - 4 } & Periyot & $15.268 \mathrm{~m} / \mathrm{s}^{2}, \mathrm{t}=8.730 \mathrm{~s}$ & $39.05 \mathrm{~m} / \mathrm{s}^{2}, \mathrm{t}=1.493 \mathrm{~s}$ \\
\cline { 2 - 4 } & Maksimum İvme & $0.396 \mathrm{~m} / \mathrm{s}, \mathrm{t}=5.820 \mathrm{~s}$ & $0.602 \mathrm{~m} / \mathrm{s}, \mathrm{t}=1.512 \mathrm{~s}$ \\
\cline { 2 - 4 } & Maksimum Hız & $0.083 \mathrm{~m}, \mathrm{t}=11.350 \mathrm{~s}$ & $0.103 \mathrm{~m}, \mathrm{t}=1.537 \mathrm{~s}$ \\
\cline { 2 - 3 } & &
\end{tabular}


European Journal of Science and Technology

Tablo 5. Ağırlıklı Olarak Yapının Deneysel ve Sayısal Analiz Sonuçlarının Karşılaştırılması

\begin{tabular}{|l|l|l|l|}
\hline \multirow{4}{*}{ Yer Hareketi 1} & Deneysel Sonuçlar & SAP2000 Analizi Sonuçları \\
\cline { 2 - 4 } & Periyot & $0.1 \mathrm{~s}$ & $0.157154 \mathrm{~s}$ \\
\cline { 2 - 4 } & Maksimum İvme & $17.647 \mathrm{~m} / \mathrm{s}^{2}, \mathrm{t}=7.070 \mathrm{~s}$ & $10.58 \mathrm{~m} / \mathrm{s}^{2}, \mathrm{t}=3.179 \mathrm{~s}$ \\
\cline { 2 - 4 } & Maksimum Hız & $0.341 \mathrm{~m} / \mathrm{s}, \mathrm{t}=7.090 \mathrm{~s}$ & $0.227 \mathrm{~m} / \mathrm{s}, \mathrm{t}=3.025 \mathrm{~s}$ \\
\cline { 2 - 4 } & Maksimum Yer Değiştirme & $0.022 \mathrm{~m}, \mathrm{t}=8.550 \mathrm{~s}$ & $0.0439 \mathrm{~m}, \mathrm{t}=3.058 \mathrm{~s}$ \\
\hline \multirow{3}{*}{ Yer Hareketi 2} & $0.1 \mathrm{~s}$ & $0.157154 \mathrm{~s}$ \\
\cline { 2 - 4 } & Periyot & $19.667 \mathrm{~m} / \mathrm{sn}^{2}, \mathrm{t}=9.190 \mathrm{~s}$ & $20.92 \mathrm{~m} / \mathrm{s}^{2}, \mathrm{t}=3.180 \mathrm{~s}$ \\
\cline { 2 - 4 } & Maksimum İvme & $0.405 \mathrm{~m} / \mathrm{s}, \mathrm{t}=9.040 \mathrm{~s}$ & $0.449 \mathrm{~m} / \mathrm{s}, \mathrm{t}=3.025 \mathrm{~s}$ \\
\cline { 2 - 4 } & Maksimum Hız & $0.037 \mathrm{~m}, \mathrm{t}=8.040 \mathrm{~s}$ & $0.0894 \mathrm{~m}, \mathrm{t}=3.057 \mathrm{~s}$ \\
\cline { 2 - 4 } & Maksimum Yer Değiştirme & $0.12 \mathrm{~s}$ & $0.157154 \mathrm{~s}$ \\
\hline \multirow{3}{*}{ Yer Hareketi 3} & Periyot & $21.251 \mathrm{~m} / \mathrm{s}^{2}, \mathrm{t}=5.530 \mathrm{~s}$ & $41.72 \mathrm{~m} / \mathrm{s}^{2}, \mathrm{t}=3.180 \mathrm{~s}$ \\
\cline { 2 - 4 } & Maksimum İvme & $0.537 \mathrm{~m} / \mathrm{s}, \mathrm{t}=5.500 \mathrm{~s}$ & $0.894 \mathrm{~m} / \mathrm{s}, \mathrm{t}=3.025 \mathrm{~s}$ \\
\cline { 2 - 4 } & Maksimum Hız & $0.071 \mathrm{~m}, \mathrm{t}=6.460 \mathrm{~s}$ & $0.178 \mathrm{~m}, \mathrm{t}=3.058 \mathrm{~s}$ \\
\cline { 2 - 4 } & Maksimum Yer Değiştirme &
\end{tabular}

Sonuçlar incelendiğinde, sayısal çalışmadan elde edilen sonuçların deneysel çalışma sonuçlarını genel olarak desteklediği görülmektedir. Süre farkları, deneysel çalışmada kayıt alındıktan bir süre sonra depremin verilmesinden kaynaklanmaktadır. Yapının ağırlıksız olması durumunda yapılan deneysel çalışma ile sayısal çalışma sonuçları arasında yaklaşık \%25 gibi bir fark görünmekle beraber, periyot değerlerinin birbirine oldukça yakın olduğu da tespit edilmiştir.

Yapının ağırlıklı haliyle yapılan sarsma tablası deneyi sonuçları ile sayısal çalışma sonuçları arasında ise yaklaşı \% $\% 50$ gibi bir fark bulunduğu tespit edilmiştir. Ağırlıklı durumda da, deneysel ve sayısal çalışmada periyot değerlerinin birbirine oldukça yakın olduğu tespit edilmiştir.

Deneysel ve sayısal çalışmalardan elde edilen sonuçlardaki farkın sebebinin, deneylerdeki sınır şartlarının, Sap2000 programında tam olarak modellenememesi ve rijit diyafram kabulü olarak değerlendirilmektedir. Diğer taraftan; ivme, hız ve yerdeğiştirme grafiklerinin benzer karakterde olması, çalışmada yapılan kabullerin isabetli olduğunu göstermektedir.

\section{Kaynakça}

Özmen, B., 17 Ağustos 1999 İzmit Körfezi Depreminin hasar durumu (rakamsal verilerle), TDV/DR 010-53, 2000, Türkiye Deprem Vakfi, 132 sayfa.

Ağcakoca, E., Yüksek katlı yapının sarsma tablası üzerinde deprem performansının incelenmesi, ALKÜ Fen Bilimleri Dergisi 2019, 1(3): 132-143 sayfa.

Türker, H.T., Mertayak, C., Çolak, H., Periyot hesaplamasında P- $\Delta$ etkisi: sarsma tablası deneyi, 1. Türkiye Deprem Mühendisliği ve Sismoloji Konferans1 11-14 Ekim 2011 - ODTÜ - ANKARA.

Torun, A., Çunkaş, M., İki eksende salınım yapan sarsma tablası tasarımı ve gerçekleştirilmesi, AKÜ Fen Bilimleri Dergisi 2009-02 ,85-96 sayfa.

Çelik, S.B., Kumsar, H., Aydan, Ö., Motion parameters of a mechanical shaking table and an application, Pamukkale Üniversitesi Mühendislik Bilimleri Dergisi, Cilt 19, Say1 5, 2013, Sayfalar 224-230.

Akansel, V.H., Kazaz, İ., Yakut A., Gülkan, P., Perde duvarlı binaların deprem etkileri altındaki davranışlarının modellenmesi ve simülasyonu, Cilt: Sayı: 1, 1, 3-9 Aralık 2010 Dicle Üniversitesi Mühendislik Fakültesi 1, 31-40.

Değer, Z.T., Betonarme bir deney binasının hasar düzeyinin Türk Deprem Yönetmeliği'ne (DBYBHY, 2007) göre belirlenmesi, Journal of the Faculty of Engineering and Architecture of Gazi University 32:2 (2017) 481-488.

Alemdar, Z.F., Betonarme köprü kolonlarında plastik mafsal bölgelerinin modellenmesi, IMO Teknik Dergi, 2015 7279-7286.

Kamanlı, M., Balık, F.S., Deprem yükü etkisi altında kalan çatı kalkan duvarlarının davranışı, Yıı 2004, Cilt 19, Sayı 1, Sayfa 49 - 64.

Şahin, Ö., Çağlar, N., Çelebi, E., Küçük ölçekli sarsma tablası test modelleri için uygun ölçeklendirme katsayısının araştırılması, 2017 Published in 5th International Symposium on Innovative Technologies in Engineering and Science 29-30 September 2017.

Özkaynak, H., Özsoy, A.E., Yapı dinamiği deneylerinin inşaat mühendisliği eğitimindeki rolü: Küçük ölçekli yapı modellerinin sarsma masası ile test edilmesi, TMMOB İnşaat Mühendisleri Odası, İnşaat Mühendisliği Eğitimi Sempozyumu, 56-64.

Karaahmetli, S., Dündar, C., Yapı sönüm oranının belirlenmesinde kullanılan yöntemlerin sayısal ve deneysel olarak incelenmesi, 4. Uluslararası Deprem Mühendisliği ve Sismoloji Konferans1 11-13 Ekim 2017 - ANADOLU ÜNIVERSİTESİ - ESKİ̧EHIR.

Bairrao, R., Vaz, C.T., Shaking table testing of civil engineering structures - the lnec 3d simulator experience, 12WCEE 2000 : 12th World Conference on Earthquake Engineering, Auckland, New Zealand, Sunday 30 January - Friday 4 February 2000.

Bahçecioğlu, A. Ş., Planda düzensiz yapıların deprem etkileri altındaki davranışı, Doktora Tezi, Fen Bilimleri Enstitüsü, (2015).

Polat, G., Betonarme yüksek yapılarda kullanılabilecek taşıyıcı sistemler ve perde-çerçeveli bir yapının statik ve dinamik hesabı, Doktora Tezi, İstanbul Teknik Üniversitesi, Fen Bilimleri Enstitüsü, (2015), İstanbul.

Demir, A. ve Dönmez, D. (2008). Çok katlı yapılarda burulma düzensizliğine etki eden faktörler, Celal Bayar Üniversitesi, Fen Bilimleri Dergisi, 2008, 4(1).

Şahin H, Alyamaç KE, Erdoğan A.S., Perdeli çerçeveli yapılarda zemin sınıfı ve kat adedi dikkate alınarak gerekli perde oranının tespiti, SDU International Technologic Science, 2013, Cilt:5, say1:1 s:74-86, 2013.

Sayın E, Yön B, Calayır Y., Perde konumunun ve zemin sınıfinın betonarme yapılardaki hasar oranına etkisi, Erciyes Üniversitesi, Fen Bilimleri Enstitüsü Dergisi, (2010), Cilt:26, Sayı:1, s:1-6.

e-ISSN: 2148-2683 
Özsoy AE, Özgen K., Perdelerdeki boşlukların yatay ötelenmeye etkisi, (2005, Deprem Sempozyumu, Kocaeli.

Işı, M., Çok katlı betonarme yapılarda taşıyıcı sistem etkisi, Doktora Tezi, Fen Bilimleri Enstitüsü, (2015).

Qiu, C., Zhu, S., Shake table test and numerical study of self-centering steel frame with SMA braces, (2017), Earthquake Engineering \& Structural Dynamics, 46(1), 117-137.

Goggins, J., Broderick, B. M., Elghazouli, A. Y., Salawdeh, S., Hunt, A., Mongabure, P., English, J., Shake table testing of concentrically braced steel structures with realistic connection details subjected to earthquakes, (2018), In Structures (Vol. 13, pp. 102-118). Elsevier.

Fiorino, L., Macillo, V., Landolfo, R., Shake table tests of a full-scale two-story sheathing-braced cold-formed steel building, (2017), Engineering Structures, 151, 633-647.

Fiorino, L., Bucciero, B., Landolfo, R., Shake table tests of three storey cold-formed steel structures with strap-braced walls, (2019, Bulletin of Earthquake Engineering, 17(7), 4217-4245.

Nasery, M. M., Hüsem, M., Okur, F. Y., Altunişik, A. C., Damage effect on experimental modal parameters of haunch strengthened concrete-encased composite column-beam connections, (2019), International Journal of Damage Mechanics, 1056789519843330. 